IRSH 63 (2018), Special Issue, pp. $25-43$ doi: I0.1017/S002085901 8000202

(C) 20 I 8 Internationaal Instituut voor Sociale Geschiedenis. This is an Open Access article, distributed under the terms of the Creative Commons Attribution licence (http://

creativecommons.org/licenses/by/4.0/), which permits unrestricted re-use, distribution, and reproduction in any medium, provided the original work is properly cited.

\title{
The Andaman Islands Penal Colony: Race, Class, Criminality, and the British Empire*
}

\author{
CLARE ANDERSON \\ School of History, Politics and International Relations \\ University of Leicester \\ University Road, Leicester $L E_{I}>R H, U K$ \\ E-mail: ca26@le.ac.uk
}

\begin{abstract}
AвSTRACT: This article explores the British Empire's configuration of imprisonment and transportation in the Andaman Islands penal colony. It shows that British governance in the Islands produced new modes of carcerality and coerced migration in which the relocation of convicts, prisoners, and criminal tribes underpinned imperial attempts at political dominance and economic development. The article focuses on the penal transportation of Eurasian convicts, the employment of free Eurasians and Anglo-Indians as convict overseers and administrators, the migration of "volunteer" Indian prisoners from the mainland, the free settlement of Anglo-Indians, and the forced resettlement of the Bhantu "criminal tribe". It examines the issue from the periphery of British India, thus showing that class, race, and criminality combined to produce penal and social outcomes that were different from those of the imperial mainland. These were related to ideologies of imperial governmentality, including social discipline and penal practice, and the exigencies of political economy.
\end{abstract}

\section{INTRODUCTION}

Between 1858 and 1939, the British government of India transported around 83,000 Indian and Burmese convicts to the penal colony of the Andamans, an island archipelago situated in the Bay of Bengal (Figure I). In terms of the total number of convicts received, this renders the

\footnotetext{
* The research leading to these results received funding from the European Research Council under the European Union's Seventh Framework Programme (FP/2007-2013)/ERC Grant Agreement 3I2542. It also received support from the Economic and Social Research Council (award no. RES-000-22-3484). I thank Shabnum Tejani for inviting me to share an early version of this work at the history research seminar at SOAS, University of London, and the participants at that gathering for their insightful comments. I also thank Keith Wilson for allowing me access to his private papers on the Deakes family, and especially Eileen Arnell for her support for this research.
} 
Andamans the largest penal colony in the entire British Empire. A rich historiography has elucidated aspects of the Islands' history with respect to penal colonization, indigenous marginalization, convict work, and resistance, as well as Britain's use of the Islands as a place for the incarceration of Indian nationalists. ${ }^{\mathrm{I}}$ Missing from these accounts of British dominance, Andamanese destruction, and Indian subjugation is an appreciation of the racial and cultural spaces in between them. Attention to this reveals the presence of various non-convict populations in the Andamans, each sent to the Islands under peculiarly colonial conditions. Here, the British reconfigured imprisonment and transportation in mainland India into new modes of carcerality and coerced migration, in which relocation to the imperial peripheries underpinned attempts at political dominance and economic development.

First, the British shipped dozens of Eurasian convicts (i.e. convicts of European and Indian parentage) to the Andamans from the first years of occupation, and, into the twentieth century, routinely employed free Eurasians in the running of the penal colony. They became intermediaries between British officials and the Indian and Burmese convict classes, and the social, cultural, and economic artificiality of the penal colony rendered government extraordinarily reliant on them. ${ }^{2}$ Second, after the Indian jails committee recommended the abolition of penal transportation in its scathing report on the Andamans in 1919-1920, the British looked to other forms of coerced migration and settlement. They looked again to AngloIndians (as Eurasians were called after I9II), this time as free settlers, and offered mainland prisoners the opportunity to go to the Islands as "voluntary" settlers, under favourable penal terms. ${ }^{3}$ They also deported nearly 2,000 Mapalah rebels, with their families, to the Andamans, in the aftermath of the 192 I Malabar Rebellion. Finally, the British sponsored the Salvation Army to resettle in the Islands several hundred men, women, and

I. Clare Anderson, Madhumita Mazumdar, and Vishvajit Pandya, New Histories of the Andaman Islands: Landscape, Place, and Identity in the Bay of Bengal, I790-20I2 (Cambridge, 2016); S.N. Aggarwal, The Heroes of Cellular Jail (Patiala, 1995); L.P. Mathur, Kala Pani: History of Andaman and Nicobar Islands with a Study of India's Freedom Struggle (New Delhi, I985); Satadru Sen, Disciplining Punishment: Colonialism and Convict Society in the Andaman Islands (New Delhi, 2000); Taylor C. Sherman, "From Hell to Paradise? Voluntary Transfer of Convicts to the Andaman Islands, I92 I-1940", Modern Asian Studies, 43:2 (2009), pp. 367-388; Pramod Kumar Srivastava, "Resistance and Repression in India: The Hunger Strike at the Andaman Cellular Jail in 1933", Crime, History and Societies, 7:2 (2003), pp. 81-102; Aparna Vaidik, Imperial Andamans: Colonial Encounter and Island History (Basingstoke, 2010).

2. Until the г9г I Census, "Anglo-Indian" described British people living in India. The words "Eurasian" and occasionally "Indo-European" signalled mixed heritage, with European descent always measured through the patrilineal line. After the i9i I Census, the term "Anglo-Indian" replaced "Eurasian". Note that people of Anglo-Burmese heritage were a significant element of the census category, though they were not usually distinguished from each other.

3. Report of the Indian Jails Committee, 1919-20 (London, I92 I), ch. II. See also Sherman, "From Hell to Paradise?". 
children from the north Indian Bhantu "criminal tribe". The presence of Eurasians/Anglo-Indians, "volunteer” prisoner settlers, Mapalah rebels, and resettled "criminal tribe" families in the Andamans raises key questions about the social and economic dynamics of the British Empire in India. This article explores the importance of class, race, and criminality to ideologies of imperial governmentality, including social discipline and penal practice, and political economy.

A vital context for understanding the history of the Andamans is that governance in the Islands was fundamentally different to that in the mainland Indian Empire. From the first year of permanent occupation in 1858 , the British wavered between a policy of containing, assimilating, and destroying the Islands' indigenous populations. ${ }^{4}$ Equally, in contrast to the rest of the subcontinent, the British had responsibility for almost every area of cultural and social life. As for the economy, Kiran Dhingra noted recently: "the arrangement of work proceeded at the behest and under the control of the government, commanded not by the economic forces of demand and supply, but organized and directed by the government to serve its needs, where the workers were all convicts, receiving wages as decreed, and selling their produce at fixed rates to the government". S Concerns about security worked against the employment of free Indians in government service. In the aftermath of the Great Revolt of 1857 (the catalyst for the occupation of the Islands) the British feared that their presence would stimulate anti-colonial conspiracies. It is important to stress, also, that, until the I920s, there were no entrepreneurs or free settlers in the Andamans; the government of India considered the commercial development of the Islands as entirely secondary to their primary penal function. It prohibited free settlement, arguing that it would lead to an inevitable relaxation in penal discipline. ${ }^{6}$

This article begins with a discussion of the important role that Eurasian convicts played in Britain's occupation of the Andamans in I 858 . It moves on to explore the transfer of Eurasian prisoners from mainland Indian jails to the Islands, and their work as convict overseers under probationary licences in the I860s. It argues that Eurasian convicts and prisoners occupied the racial interstices of a British penal colony for Indian subjects. By the early decades of the twentieth century, the boundaries of race in the

4. Clare Anderson, "Colonization, Kidnap and Confinement in the Andamans Penal Colony, I77 I-I 864", Journal of Historical Geography, 37:I (20I I), pp. 68-8I; Satadru Sen, Savagery and Colonialism in the Indian Ocean: Power, Pleasure and the Andaman Islanders (New York, 2010). 5. Kiran Dhingra, The Andaman and Nicobar Islands in the Twentieth Century: A Gazetteer (New Delhi, 2005), p. 227.

6. National Archives of India (NAI) Home (Port Blair) A proceedings January i 88 3, nos 36-9: J. H. Roberts to Secretary to Government of India, 25 August I 882; M. Protheroe to Secretary to Government of India, 31 October I882; note of D[onald] M[artin] S[tewart] (former Chief Commissioner and member of council for the Secretary of State for India), 27 December I 882. 
Andamans were more fluid than those of the mainland, and though they never occupied the highest office, Anglo-Indians were routinely employed in key government positions. Moreover, it was quite common for newly arrived British and country-born ${ }^{7}$ men and women to marry into Anglo-Indian families in the Islands. This blurred the boundaries around the meaning of "Anglo-Indian", which in the Andamans came to stand not necessarily for people of European and Indian heritage, but for free people generally of the non-elite or subordinate official classes. The article moves on to examine the relocation of "volunteer" prisoners and Mapalahs, and then focuses in particular on the Salvation Army's Bhantu migration scheme. By placing these different categories of coerced migrants in the same frame of analysis, it argues for a multi-sited perspective from the colonies, in which officials sought to balance the demands emanating from different points of empire with those coming from different ideological vantage points.

\section{EURASIAN AND EUROPEAN CONVICTS AND OVERSEERS}

Eurasians were present in the Andamans at the first moment of permanent colonial occupation. After the British decided to establish a penal colony in the Islands in late I 857, executive engineer and superintendent of convicts in the nearby Burmese penal settlement in Moulmein, Henry Man, spent two months on Chatham Island. There, he raised the Union flag and, with a party of more than a dozen Eurasian men, and under the pretence that the Islands were terra nullius (nobody's land), prepared for the arrival of Indian convicts. Previously, the East India Company had routinely sent Eurasian convicts from India to penal settlements scattered along the Burmese coast. The British treated them quite differently to Indians, ensuring that they travelled in different compartments on transportation ships, lived in separate accommodation, wore distinct clothing, ate different rations, and were employed not at hard labour, but as clerks or servants. Their literacy, numeracy, and familiarity with South Asia and native languages made them very useful to the British penal establishment, and its efforts to communicate effectively with Indian transportation convicts. ${ }^{8}$ The British arrived in the Andamans with the first batch of Indian convicts in March I 858 , and soon afterwards transferred some of the Eurasian convicts in Burma to the Islands, to work as convict overseers. One such man was James David, described as a "Portuguese Eurasian" and originally transported to the Tenasserim Provinces in I 857 for murder. He went on to play a significant

7. White people born in India.

8. Clare Anderson, Subaltern Lives: Biographies of Colonialism in the Indian Ocean World, I790-I920 (Cambridge, 20I2), pp. 69-72. More generally, and for the earlier period, see C.J. Hawes, Poor Relations: The Making of a Eurasian Community in British India 1773-I 833 (London, 1996). 


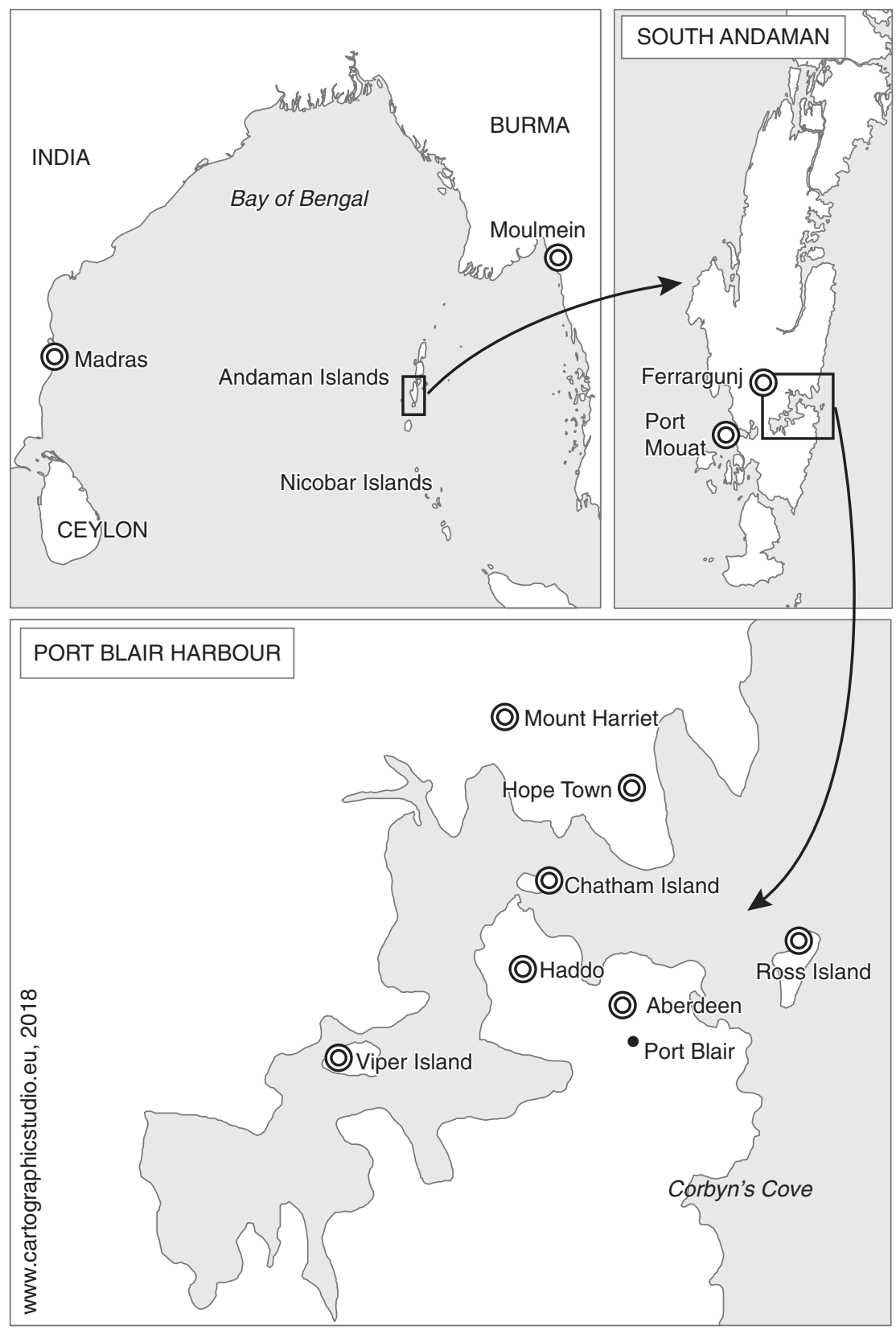

Figure I. Andaman Islands, North Andaman, Port Blair Harbour. 
role in the first contact missions between the colony and indigenous islanders, as well as working as a bookbinder in the superintendent's office. After serving a sentence of twenty years, ultimately he returned to a life of poverty in the Indian city of Madras. ${ }^{9}$

European and American convicts were also present in the Islands. In the years before the colonization of the Andamans, such convicts found guilty of transportation offences in India had been sent to Britain's penal colonies in Australia: New South Wales, Van Diemen's Land (Tasmania), and Western Australia. They were not expected to serve their sentences in the largely Indian penal settlements, which were then located in the Straits Settlements (Penang, Malacca, and Singapore) as well as Burma. But, in a surprise move in 1857 , the only such destination still open, Western Australia, informed the government of India that it would no longer accept such convicts. And so the Indian authorities commuted the sentences of those men awaiting transportation to terms of penal servitude, and subsequently transferred many to the Andamans. ${ }^{10}$ It is important to note that these early transfers took place in the years following the i 857 Revolt, when the racial lines in the Indian subcontinent had hardened, and Indians and non-Indians became increasingly separate. However, at this time, Indian and non-Indian prisoners were incarcerated in the same jails (though in different wards). The British administration instigated the Andaman transfers during the period before it opened entirely separate jails for Europeans in India: in Ootacamund (Madras Presidency) in 1862 and Hazaribagh (Bengal Presidency) in I 865. Meanwhile, drawing on what has been described elsewhere as the relative privilege of "the racial dividend", ${ }^{\text {I }}$ European prisoners were given tickets of conditional release (probationary licences), subject to residence in the Andamans with continuing good behaviour. All had at least three years of their sentence to serve, and had

9. India Office Records, British Library (IOR) P/434/8 India (Public) i I December i 867: Inspection report by Major H.N. Davies, Secretary to the Chief Commissioner of British Burma, enc. Nominal roll showing the number of European, Eurasian, and Native convicts receiving upwards of Rs. 8 a month, on the 23 rd April, at the several settlements of Port Blair; Tamil Nadu State Archives (TNSA) Madras (Judicial) 27 July I877, i 5 I-6: Memorandum of D.F. Carmichael, Chief Secretary to the Madras government, to the Commissioner of Police Madras, 8 June 1877.

ı०. TNSA Madras (Judicial) s April ı869, nos 66-7: H. Man, officiating Superintendent Port Blair, to R.S. Ellis, Chief Secretary to Madras government, 9 February i 869, enc. petition of Martin Murphy, 23 January i 869. Fragmentary evidence from judicial proceedings in Bengal, Bombay, and Madras Presidency suggest that a handful of ticket-of-leave Europeans (i.e. prisoners on probation) were sent to Western Australia, until at least i 859.

I I. Harald Fischer-Tiné, "Hierarchies of Punishment in Colonial India: European Convicts and the Racial Dividend, c.1860-1890", in idem and Susanne Gehrmann (eds), Empires and Boundaries: Rethinking Race, Class, and Gender in Colonial Settings (London, 2008), pp. 4I-65. 
skills of immediate use in the new colony. Included among them were carpenters, bricklayers, blacksmiths, sailors, and clerks. ${ }^{\text {I2 }}$

For the first two or three years after Britain's occupation of the Andamans, the Indian convicts were grouped into broad penal classes, their employment determined by a combination of their skills and behaviour. The first class were clerks and overseers of other convicts; the second were allowed to become self-supporting tradesmen (including tailors, bakers, shoemakers, and fishermen); and the third were put to work as ordinary labourers. At this time, there was a great shortage of what Superintendent J.C. Haughton called "steady and intelligent" overseers, particularly Europeans. ${ }^{13}$ Following the success of the European transportation convict scheme, the mainland administration decided to offer European prisoners in India generally the opportunity of release conditional on taking service in the Islands. News of the possibility of transfer spread fast, and dozens of prisoners made enquiries about their prospects in Port Blair. "I am well acquainted with the Hindoostanee language and the people and will be of better service to government than if I remain here for 4 years

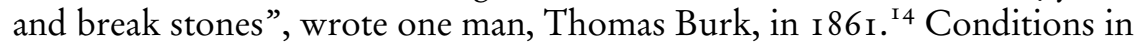
Indian jails in the nineteenth century were so grim that there was no shortage of applications and petitions. European prisoners, it would seem, were keenly aware of the relative openness of the Andamans penal colony, and the fifty rupees per month that they would receive as wages. ${ }^{\text {Is }}$ Meanwhile, as these European overseer prisoners arrived and took up their post, the new officiating Superintendent of the Andamans, R.C. Tytler, expressed delight about the effect that their presence had on penal discipline. He wrote to the governor of Calcutta jail in 1862 that the Indian convicts did more work under their supervision than had been the case previously. ${ }^{16}$

Though the majority of the Indian transfer prisoners were European, included among them were several Eurasians and at least two

I 2. IOR P/I 46/29 Bengal (Jails) i 7 July i 860, nos 48-55: proposal to transfer European prisoners to Port Blair. S. Wauchope, Commissioner of Police Calcutta to Rivers Thompson, Junior Secretary to the government of Bengal, 2 June I 860; J.C. Haughton, Superintendent Port Blair, to W. Grey, Secretary to the government of India, I 3 June I 860.

I3. IOR P/206/62 India (Judicial) 6 January I 860: Superintendent J.C. Haughton to W. Grey, Secretary to the government of India, I 3 November i 859 .

I4. IOR P/I 45/38 Bengal (Jails) March I 86r: S. Wauchope, Commissioner of Police Calcutta, to Rivers Thompson, Junior Secretary to the government of Bengal, 22 February I 86I, enc. petition of M.R. Crawford, i 8 February i 86I, petition of Thomas Burk, I6 February i 86 I; TNSA Madras (Judicial) 4 March i 863: J. Rohde, Inspector-General of jails Madras, to A.J. Arbuthnot, Chief Secretary to the government of Madras, 2 I November 1862.

I 5. TNSA Madras (Judicial) 4 March I863, nos 6-I I: Rohde to Arbuthnot, 2 I November I 862. I6. IOR P/I46/53 Bengal (Jails) November I862: J. King, Governor Calcutta Jail, to David Cowie, Sheriff of Calcutta, I4 August 1862. 
African-Americans. The government selected them for tickets of conditional release on the basis of their literacy and skills, in precisely the same way as for white convicts. Eurasian Santiago Gregory had been employed previously on the railways, could fell and hew timber, and make sails. $\mathrm{He}$ also spoke Bengali and Hindustani. ${ }^{17}$ A thirty-two-year-old "coloured" American convict, John Peterson, was a ship's cook and steward by trade, and had also worked as a butcher. He was said to understand farming and tobacco planting, which perhaps hints at his previous enslavement. ${ }^{\mathrm{I}}{ }^{8}$ Another prisoner, William Hawkins, said to be "of African descent", was described by J. Rohde, the Inspector-General of jails in Madras, as "a good cook, and a man of intelligence". Rohde expressed anxiety that the fact of his African birth "might not allow of his exercising the same control as others". The Madras government disagreed, and shipped Hawkins to Port Blair. ${ }^{19}$ The British were as unconcerned about race as they were about crime in the selection of prisoners for transfer; any non-Indian prisoner could petition and be chosen. The Eurasian and black prisoners had been convicted of burglary, stealing, robbery, manslaughter, and murder; and two had even previously attempted to escape from jail. Just as for Europeans, it was fitness, "character", and prisoner skills that decided their transfer. Almost all had previously been to sea, and they knew sail, rope, mat, brick, and shoemaking, as well as carpentry and weaving. ${ }^{20}$ These transfers continued after separate European jails opened during I862-1865. However, both before and afterwards, the British did not send either mainland prisoners with poor disciplinary records, or soldiers, who were ineligible for transfer. ${ }^{2 \mathrm{I}}$

I7. IOR P/I 46/53 Bengal (Jails) October I 862: A. Payne, officiating Inspector-General of jails, to J. Geoghegan, Under-Secretary to the government of Bengal, 9 September i 862; memorandum of A. Payne, 29 September i 862.

I 8. IOR P/I 46/50 Bengal (Jails) May I 862: J. King, Governor of Calcutta Jail, to David Cowie, Sheriff of Calcutta, I May i862, enc. petition of John Peterson, an American under sentence of penal servitude for six years, at present detained in Calcutta Jail, 2 May i 862; roll of an American (coloured) convict, I May i 862.

19. TNSA Madras (Judicial) 24 June I 863: J. Rohde, Inspector-General of jails Madras, to A.J. Arbuthnot, Chief Secretary to the government of Madras, 25 May 1863; Arbuthnot to E.C. Bayley, Secretary to the government of India, 8 October I 863.

20. TNSA Madras (Judicial) 24 June I 863: W.S. Nesbitt, in charge of European prison Ootacamund, to Rohde, 25 April I 863, enc. List of prisoners undergoing penal servitude in the Ootacamund European prison who are considered eligible for employment in Port Blair; TNSA Madras (Judicial) is July i 864, nos i 85-6: E.C. Bayley, Chief Secretary to the government of India, to A.J. Arbuthnot, Chief Secretary to the government of Madras; TNSA Madras (Judicial) 8 December I 864, I I9-2 I: J. Rohde, Inspector-General of jails, to A.J. Arbuthnot, Chief Secretary to the government of Madras, 24 November and 2 December 1864, enc. petition of Thomas Nolan, 26 October I864; TNSA Madras (Judicial) i6 January i866: Bayley to Superintendent Barnett Ford, I6 January i 866.

2 I. TNSA Madras (Judicial) 24 June I 863: J. Rohde, Inspector-General of jails Madras, to A.J. Arbuthnot, Chief Secretary to the government of Madras, 25 May i863; Arbuthnot to E.C. Bayley, secretary to the government of India, 8 October I 863 . 
By I867, there were thirty-four European, Eurasian, and American prisoners in the Andamans, employed as clerks, painters, fishermen, and carpenters. There were 6,965 Indian convicts in the Islands at this time. ${ }^{22}$ The majority of non-Indian prisoners - European, Eurasian, African, and American - worked as convict overseers, either in agricultural cultivation or on public works. About half lived on Ross Island, at the time the headquarters of the penal colony. Reflecting their work in supervising the convict gangs working around the settlement, the other half was spread around the bay of Port Blair: across Aberdeen, Haddo, Chatham Island, Viper Island, and Mount Harriet, with one man at, respectively, Perseverance Point, Hope Town, Navy Point, and Port Mouat. ${ }^{23}$ They came from many different places, including: the United States, London, Scotland, and Ireland; Calcutta, Madras, Allahabad, and Patna in India; and, even further afield, Manila, Amsterdam, Persia, and Ceylon. ${ }^{24}$ The Andamans regime valued the presence, labour, and authority of these men, and it did not employ them differently based on racial lines. ${ }^{25}$ The first census of the Islands, taken in December I 87 I, noted that there were 233 "British-born" men and women in the Islands, sixty-nine of whom had, in fact, been born in India. Most were settlement officials or soldiers. Further classifications reveal the presence of three Americans, six Africans, and sixty-four Eurasians - a rise on the I 867 figures. The total convict population in $\mathrm{I} 87 \mathrm{I}$ was 8,643 , and the indigenous Andamanese population was estimated at $2,847 .{ }^{26}$

Until the I870s, these Europeans, Eurasians, Americans, and Africans mixed freely with each other - whether they were transportation convicts or prisoners transferred on licence. All were grouped together and separated from Indians in a "Christian barrack", where they enjoyed a life of relative

22. UK Parliamentary Papers 53.269: Statement Exhibiting the Moral and Material Progress and Condition of India During the Year I 868-69 (London, I870), p. 65.

23. TNSA Madras (Judicial) I 6 January i 866: A.J. Arbuthnot, Chief Secretary to the government of Madras, to Superintendent Barnett Ford, 3 I January I 866; IOR P/434/8 India (Public) I I December I867: Inspection report by Major H.N. Davies, Secretary to the Chief Commissioner of British Burma, enc. Nominal roll showing the number of European, Eurasian, and Native convicts receiving upwards of Rs. 8 a month, on the 23 rd April, at the several settlements of Port Blair; List of European and Eurasian prisoners on the various stations of the settlement and their employment. 24. IOR P/434/8 India (Public) i I December i 867: Inspection report by Major H.N. Davies, Secretary to the Chief Commissioner of British Burma, enc. Nominal roll showing the number of European, Eurasian, and Native convicts receiving upwards of Rs. 8 a month, on the $23 \mathrm{rd}$ April, at the several settlements of Port Blair.

25. IOR P/I46/52 Bengal (Jails) September i 862: Extract from a demi-official letter from the Superintendent of Port Blair to E.C. Bayley, Secretary to the government of India, I August I 862. 26. NAI Home (Port Blair) October I 873, nos 49-59: Census of the Andaman Islands, December I 87 I. The Andaman census was not included in the published Indian census "as not being strictly within Indian limits". See Henry Waterfield, Memorandum on the Census of British India ${ }_{1871-72}$ (London, I875), p. 6. On indigenous people in the Islands, see Vishvajit Pandya, In the Forest: Visual and Material Worlds of Andamanese History, I858-2006 (Lanham MD, 2009). 
luxury. They were paid wages, issued with superior rations, and appear to have had easy access to liquor. Their barracks were stone built, and each man was allotted the same space as that issued to a European soldier. Indian convicts on the other hand lived in wooden barracks, each housing I00-I 50 men, and divided into groups of twenty-five. ${ }^{27}$ One transfer prisoner, J. Bluett, even had a child called James, who was enrolled in the school for Europeans and Eurasians on Ross Island. ${ }^{28}$ However, their life of relative privilege was short-lived. One drunken night in I871, a licenced prisoner called James Devine killed another conditional release holder (a Dutchman called Alkana) in a brawl. A murder trial followed, in which it was revealed that Devine was employed in the public works department, where another licenced prisoner Frederick Roloff worked in the commissariat, and where a third, Thomas Fernandez, was superintendent of sail makers. Devine was found guilty and despatched to the mainland under sentence of penal servitude. The mainland government subsequently urged an enquiry into why, though of different penal status, convicts and licenced prisoners lived in the same barracks, were employed in the same positions of authority, and enjoyed various privileges so soon after their transportation or transfer. In an attempt to draw a line of criminal distinction around the prisoners, it ordered the tightening up of discipline. ${ }^{29}$

That the Andaman administration met with the disapprobation of its mainland counterpart for its lack of racial distinction is indicative of the social peculiarity of the Andamans as a penal colony. The government of India, which had taken control of much of the subcontinent following the I 857 Revolt, was seemingly unaware that, in a range of largely Indian penal contexts, since the I 820 s, European, Eurasian, and African convicts had been important allies of the East India Company's disciplinary regime. ${ }^{3 \circ} \mathrm{In}$ places like Burma, the British co-opted them into convict management, and, in return, they enjoyed favourable conditions, at least compared to their fellow prisoners in Indian jails or the penal colonies of majority white settlements, including Australia. Though it may have shocked mainland free society, the Andamans penal regime was thus totally consistent with that of the earlier Indian penal settlements, where Eurasian convicts formed small proportions of the total convict population. ${ }^{3 \mathrm{I}}$ Class and race, it seems,

27. IOR P/434/8 India (Public) i I December I 867: Inspection report by Major H.N. Davies, Secretary to the Chief Commissioner of British Burma, p. I 8.

28. Ibid., enc. Memorandum showing the number of scholars, names and ages, who attended the Port Blair school from January 1867 , up to the present date. We know nothing about the child's mother.

29. NAI Home (Port Blair) 20 May I 87I, nos 2 I-2: Murder by James Devine, a licenced convict. 30. The East India Company was a trading company that governed large areas of subcontinental India before 1857 , including with regard to law and punishment.

3 I. On Eurasian convicts in South East Asia, and a biography of an African convict called George Morgan transported from India to Burma and ultimately Van Diemen's Land (Tasmania), see Anderson, Subaltern Lives, ch. 3 . 
had different meanings and produced different social formations in a penal colony such as the Andamans.

\section{ANGLO-INDIAN SERVICE}

The I90I Andamans census recorded the presence of 280 Europeans and $7 \mathrm{I}$ Eurasians in the Islands. ${ }^{32}$ This was out of a total population of 16,106 , which included I I,947 convicts and I,465 free residents, the latter including ex-convicts and their descendants. ${ }^{33}$ In I 92 I, the last census for which there is data, the number of Anglo-Indians (as Eurasians were now called) had fallen to twenty-five. This dramatic reduction in numbers was likely due to the release or death of the licenced prisoners transferred during the i 860 s. $^{34}$ Despite this, there were somewhere between two and four Anglo-Indians to every European living in Port Blair. This was an extraordinarily high proportion compared with that on the mainland. The relatively large number of Eurasians living in the Andamans at the start of the twentieth century reflected the extent to which the British relied on them to run the penal colony. They occupied almost all the senior positions in the management and operation of the jails, telegraph, forest, and wireless services. European men stationed in India went to the Islands to work in the wireless, telegraphs, and jail departments too. They commonly married the sisters and daughters of Anglo-Indians settled in the Islands, and then called for their female relatives to join them. They then married into Anglo-Indian families, creating tight knots of family and community that straddled hierarchies of race. ${ }^{35}$ Race and class intertwined in the formation of the category "Anglo-Indian", for in the Andaman Islands one could be a British, Indian, or country-born European and Anglo-Indian. In this respect, the Andamans' bounded islandness and character as a penal colony produced an interstitial socio-racial category that distinguished the peripheries of the Indian Empire in the Bay of Bengal from the cultural formations of empire on the mainland. ${ }^{36}$

32. Andaman and Nicobar Administration Archives, Port Blair (A\&N Archives): Memorandum Relative to the Deputation of the Anglo-Indian and Domiciled Community of India and Burma to the Right Honourable the Secretary of State for India, 30 July 1925.

33. R.C. Temple, Census of India, I90I, Volume III: The Andaman and Nicobar Islands (Calcutta, 1903), p. 289.

34. R.F. Lowis, Census of India, I92 I, Volume II: The Andaman and Nicobar Islands, Table XVI: European and Allied Races and Anglo-Indians by Race and Age (Calcutta, 1923), p. 73.

35. N. Francis Xavier, "A House Named Blessington", Andaman Sheekha, 6 March 201 I; author's interview with Eileen Arnell, 27 June 20 I I.

36. Compare the important insights of Elizabeth Buettner, "Problematic Spaces, Problematic Races: Defining 'Europeans' in Late Colonial India”, Women's History Review, 9:2 (2000), pp. $277-278$. 


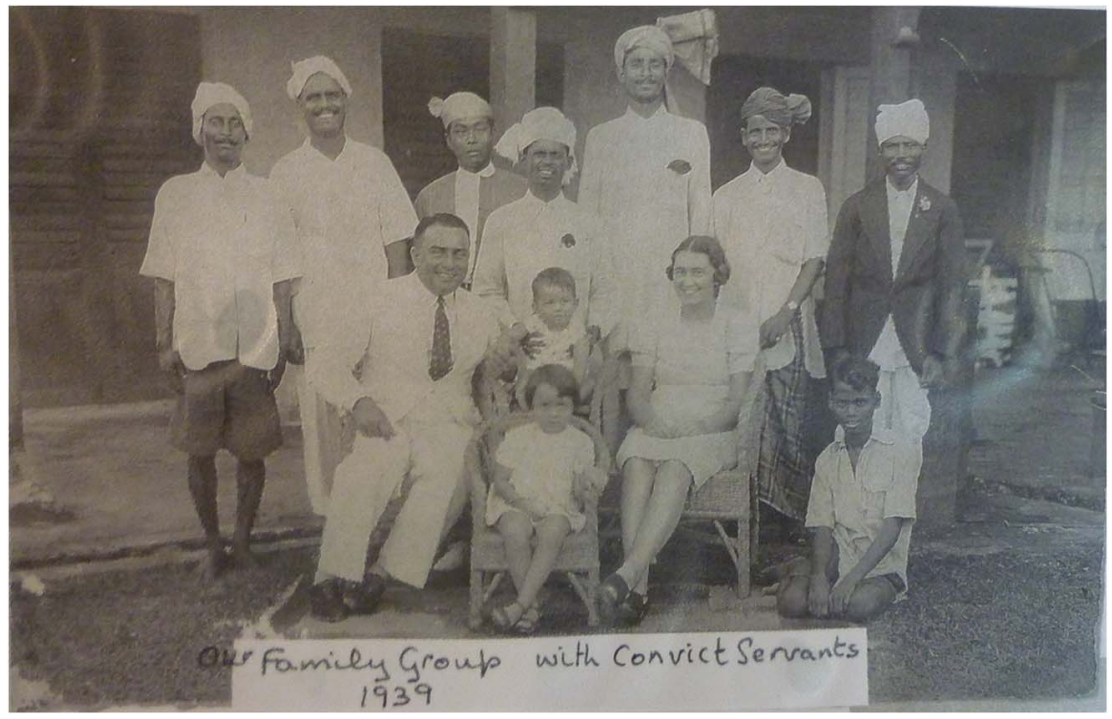

Figure 2. "Our Family Group with Convict Servants, 1939".

Private collection of Eileen Arnell, England. Used by permission.

Eileen Arnell's English grandfather Jack and great-uncle Patrick both worked as officers in the Andaman jails department. In 1933, Jack's daughter Mollie, Eileen's mother, travelled from England to the Islands, where she married an Anglo-Indian man called John Boomgardt. He was the great-grandson of an Englishman called James Whitby. Whitby went out to India in I 840, and by the I860s was stationed in the Andaman Islands. ${ }^{37} \mathrm{~A}$ few months after John and Mollie's wedding, Mollie's sister Monica travelled out and married another Anglo-Indian telegraph man. John Boomgardt's Anglo-Indian sister Coralie, meanwhile, married an Englishman stationed in the wireless department. Eileen (the little girl in the picture) was born in 1936, and a brother Peter (the baby in the photograph) a few years later. Peter died aged just fourteen months from an unknown illness.

The jail service in particular came to be almost completely staffed by Anglo-Indians. By the I930s, eight men were in daily charge of the cellular jail and the district convict stations. The cellular jail was a large radial

37. It is likely that James had a brother in the Andamans; I 867 records also record the presence of one J. Whitby, a clerk in the convict record department, as well as James Whitby, who was a sergeant in the commissariat department. Two children, Thomas Whitby and Eleanor Whitby, were at Port Blair School. See IOR P/434/8 India (Public) i I December I 867, 89-97: Inspection Report by Major H.N. Davies, B.S.C., Secretary to the Chief Commissioner of British Burma, Appendices: Nominal return of officers; Memorandum showing the number of Scholars, names and ages, who attended the Port Blair School from January i 867, up to the present date. 
structure that had opened in 1906 to receive all transportation convicts for a new, initial stage of hard discipline, before their release to convict working gangs. Almost as soon as the cellular jail opened, its function changed, for it was also used to incarcerate revolutionary nationalists being transported from the mainland. They were never sent to outdoor labour. Anglo-Indian jailers and overseers were charged with monitoring all aspects of the incarceration and penal work of both ordinary and political prisoners, including taking musters, issuing rations, and keeping registers. Well known among them was John Boomgardt (see Figure 2), who was transferred from the public works to the jails department in I $92 \mathrm{I} .{ }^{38}$ They also included two brothers by the surname of Young, and a father and son named Baines. ${ }^{39}$ The government also employed Anglo-Indians in the forest service, ${ }^{40}$ at Chatham Island sawmill, ${ }^{4 \mathrm{I}}$ and as managers of the government workshops that employed convicts. ${ }^{42}$

As noted above, following the James Devine murder trial, the Andamans administration distinguished non-Indian transportation convicts from licenced prisoners. A further layer of separation can be found in the residential patterns of Anglo-Indian government servants and the British governor and his senior officers. Indeed, socio-racial lines of distinction between them were drawn across Port Blair harbour. The British lived a lavish lifestyle in the beautiful bungalows of Ross Island, the headquarters of the penal colony. Anglo-Indians lived in more modest houses, sometimes built on stilts in a colonial South East Asian style, along a mainland urban coastline that partly faced Ross, and stretched from Corbyn's Cove to Aberdeen and Haddo. They belonged to different clubs: the British socialized on Ross Island, and Anglo-Indians went to the Temple Club near the Aberdeen Bazaar in Port Blair. Commissioner R.C. Temple had established the latter in 1903 , as a facility for Anglo-Indians. He noted at the time that it was difficult to recruit people for service in the Islands, and he wanted to create a leisure facility to draw them. ${ }^{43}$ Yet, despite their separate residence, the social demarcations between British and Anglo-Indian officers and staff were not as distinct as was the case in the mainland Indian Empire. In this extraordinary penal context, the British administrative classes viewed

38. IOR P/I I048 Home (Port Blair) January I $92 \mathrm{I}$, nos 49-52 part B: A.J. Boomgardt, transfer from the public works department to the jailor establishment of Port Blair.

39. IOR Mss Eur Fi 80 : memoirs of N.K. Paterson, n.d.; Gill Chalabi’s family papers: Noel Paterson, "Experiences of a District Officer 1929-1947", transcribed from audio, November 2004. I thank Selma Chalabi for sharing copies of the transcripts with me.

40. IOR Mss Eur Fi 80: memoirs of N.K. Paterson, n.d.

4I. Gill Chalabi's family papers: Noel Paterson, “Experiences of a District Officer 1929-I947”. 42. IOR $\mathrm{P} / \mathrm{IO}_{4} \mathrm{I}$ I Home (Port Blair) January i 920.

43. Martin Wynne (ed.), On Honourable Terms: The Memoirs of Some Indian Police Officers, I9I 5-I948 (London, I985), p. I60; IOR P/I I048 Home (Port Blair) July I 92 I, nos 4-10 part A: Chief Commissioner H.C. Beadon to Secretary to the government of India, 30 April I 92 I. 
Anglo-Indians as their allies, not just in running the penal colony, but in its security. They believed that in the event of a convict revolt or uprising, they would side with them, rather than with Indian and Burmese convicts. Though never explicit in colonial reports and correspondence, the fact of their Christianity was certainly relevant.

In a I920s memoir of the Islands, Frances Stewart Robinson, daughter of the Chief Commissioner, recalled this social ambivalence. She wrote of an annual gathering, given by the British administration in honour of the jailers and their families at the Andaman Club, where majors, captains, "dusky beauties", "Anglo-Indians", and "dignified Civil Officers from Burma and India" waltzed and foxtrotted together. "Barriers of class and colour", she noted, "were temporarily down". ${ }^{44}$ Robinson's writing anticipated that of Chief Commissioner M.L. Ferrar, who wrote in a private letter of a similarly mixed dinner party held in I929:

Everyone was cheery and sociable and well bred and we really had a very pleasant evening. Yet 5 of them were Indians, 5 were white country bred and 4 more with a lot of colour and several of the rest were of very ordinary English upbringing. I know of no other place in India where people have so little snobbery and artificiality among them. ${ }^{45}$

The Islands' remoteness from the mainland, and its peculiarly penal character, enabled such sociability. ${ }^{46}$ Moreover, despite the "barriers of class and colour" described by Frances Robinson, Anglo-Indians lived closely with non-elite European employees of empire, and enjoyed many of the trappings of colonial privilege. As one, British-born woman who had married an Anglo-Indian in the Islands, Mollie Boomgardt, recalled in a radio interview in 2010, with their weekly dances, piano playing, and convict servants, they had lived "like kings and queens". ${ }^{47}$

\section{MIGRATION IN THE 1920S: PRISONERS, REBELS, FREE ANGLO-INDIANS, AND CRIMINAL TRIBES}

In 1919-1920, under the auspices of a broader review of imprisonment, the Indian jails committee recommended the abolition of penal transportation. It reported that "unnatural vice" was widespread in the Andamans, and that convicts lacked "reformatory influences". It called for the substitution of penal transportation for rigorous imprisonment, on the grounds of morality, as well as expense. Although the committee recognized that there was insufficient jail

44. IOR Mss Eur F209: Frances Stewart Robinson, “The Forgotten Islands”, p. 32.

45. Centre for South Asian Studies, University of Cambridge: M.L. Ferrar papers, M.L. Ferrar to his mother, 4 June 1929.

46. See also Buettner, "Problematic Spaces, Problematic Races", pp. 277-278.

47. "Kala Pani: A Forgotten History", BBC Radio 4, 2 I April 2010. 
accommodation on the mainland to accomplish this goal, as criticism of the cost of the penal colony mounted, having invested so many resources in the founding of the penal colony, the British were loath to abandon it altogether, and so began to look for alternative sources of labour and settlement. To a large extent, they remained committed to coerced migration, and with the jails committee claiming that homosexual practices were widespread in the Andamans they particularly desired the migration of women. And so the British instigated a "volunteer" scheme for mainland prisoner migrants and their families, beginning in I92 I. This was not successful: most prisoners were unwilling to go to the Islands, and the authorities found it difficult to balance the often conflicting demands of punishment with those of economy. ${ }^{48}$ Second, in the wake of the mass convictions of the Malabar Rebellion of $192 \mathrm{I}-1$ 922, the government offered favourable terms to convicted rebels willing to migrate to the Islands with their families. They would immediately assume the status of "self-supporters", in effect replacing their terms of incarceration with those of probation in the penal colony. Subsequently, the government organized the transfer of about 2,000 Mapalahs, and paid the expenses of families wanting to join them. ${ }^{49}$

With respect to its desire for free labourers to open up the Islands for further settlement, and compelled to foreground the Islands' economic self-sufficiency and productivity above their punitive function, in the context of its earlier policies the British again looked to Anglo-Indians. Shortly after the Mapalah transfers, in 1923, twelve agricultural "pioneers" went to the Islands under a trial scheme. Waved off from Calcutta by the Anglo-Indian Association, the British governor of Bengal even sent them a message of support. ${ }^{50}$ However, the scheme was a disaster from start to end. The men's land allocation was fallow; they lacked agricultural skills or experience; few if any of the promised resources materialized; some of the men fell sick with malaria; and they gradually abandoned their barracks. ${ }^{5 \mathrm{I}}$

At this time, a handful of other Anglo-Indians and country-born men and women travelled to the Islands too, and they were considerably more successful than this organized party. They included George and Dorothy Deakes who, three years after they first arrived in 1923 , were granted a thirty-year licence for over fifty acres of land on Mount Harriet. ${ }^{52}$ They built a house, made improvements to the land, cleared the jungle, planted

48. Sherman, "From Hell to Paradise?". For a discussion of development in the I920s, under the stewardship of Chief Commissioner M.L. Ferrar, see Anderson et al., New Histories of the Andaman Islands, pp. 29-6I.

49. Anderson et al., New Histories of the Andaman Islands, pp. 47-49.

50. "The Colonisation Scheme: Pioneers leave Calcutta", The Times of India, 27 November 1923.

5. "Anglo-Indian Colony: Possibilities in Andamans", The Times of India, 5 April 1924. IOR MSS Eur F531/46 Hawes papers: "Report from A.E. Young, 28 January 1926", The AngloIndian, I9:3 (1926), pp. I3-I4. See also Frank Anthony, Britain's Betrayal in India: The Story of the Anglo Indian Community (Bombay, 1969), pp. vi, 91, 97-99, I I4.

52. Personal Collection of Keith Wilson (PCKW): "Grant of Land" certificate, Is August 1932. 
fruit and vegetable orchards, kept cows and poultry, and established betel as well as coconut plantations. ${ }^{53}$ By any measure, they seem to have made a good living; Dorothy Deakes later wrote that the couple had "gladly settled down as colonist planters". ${ }^{4}$ Otherwise, though the government of India announced its willingness to consider applications for land grants, there were very few. ${ }^{55}$ Most, including Deakes, already had relatives or friends working for the Andamans administration, and thus had some knowledge of the Islands. ${ }^{56}$

Following experiments with "volunteer" prisoners, Mapalahs, and free Anglo-Indian settlers, the British administration sponsored the Salvation Army to "rehabilitate" about 300 Bhantus in the Andamans. The three million members of this peripatetic community had been classified as hereditary criminals under the Criminal Tribes Acts (1872-1924), and were thus rounded up and forced to live on reserved land in India's Central Provinces. The Salvation Army had first petitioned the government of India regarding the prospect of settling criminal tribes in the Andamans in 1914. Special Commissioner Frederick Booth Tucker wrote: "The absence of the woman element in the present colonies is a well-known and growing evil, the seriousness of which can hardly be exaggerated". Families, he argued, would rapidly multiply and populate the Andamans, and once emigration became attractive, compulsion would no longer be necessary. ${ }^{57}$ However, it was not until 1926-1928 that the British offered those Bhantus convicted in the criminal courts (largely for dacoity, or armed gang robbery), and incarcerated in mainland jails, the chance of paid passage to the Andamans. The conditions were as follows. First, they would be accompanied by officers of the Salvation Army, which they knew as Mukti Fauj. Second, they had to have been sentenced to at least ten years. Third, though they would be volunteers, they had to take their relatives with them. The convicts would be under penal restraint, but their families would have entire freedom of mobility. Despite these constraints, the British promised that, until they had acquired land and built houses, they would receive a subsistence allowance.

In I 926, Salvation Army Captain Edwin Sheard (known in India as Fauj Singh), with his wife, took around Ioo convicted Bhantu dacoits with about

53. PCKW: D.M. Deakes to the Secretary to the government of India, Home Department, 25 April 1946; Board of Trade, extended Far Eastern private chattels scheme (war damage), application of Mrs Millicent Dorothy Deakes, undated (1950).

54. Mrs Milicent D. Deakes, "Isles of Peace and Happiness", The Times of India, I 2 March 1950. 55. Home Department Resolution, 27 February 1 826, reproduced in Andaman and Nicobar Gazette: Extraordinary, I8 March 1926; "Future of the Andamans: Conversion to a SelfSupporting Community", The Times of India, I March 1926.

56. Deakes, "Isles of Peace and Happiness".

57. IOR P/9949 Home (Port Blair) April I9I4 no. Io proposed establishment of a settlement in the Andaman and Nicobar Islands for criminal tribes from India: Frederick Booth Tucker, special commissioner for India and Ceylon, Salvation Army, Simla, to Reginald Craddock, Delhi, 2 March I9r 4. See also Frederick Booth-Tucker, Criminocurology or the Indian Crim, and What to Do With Him: Being a Review of the Work of The Salvation Army Amongst the Prisoners, Habituals and Criminal Tribes of India (Simla, 1916). 


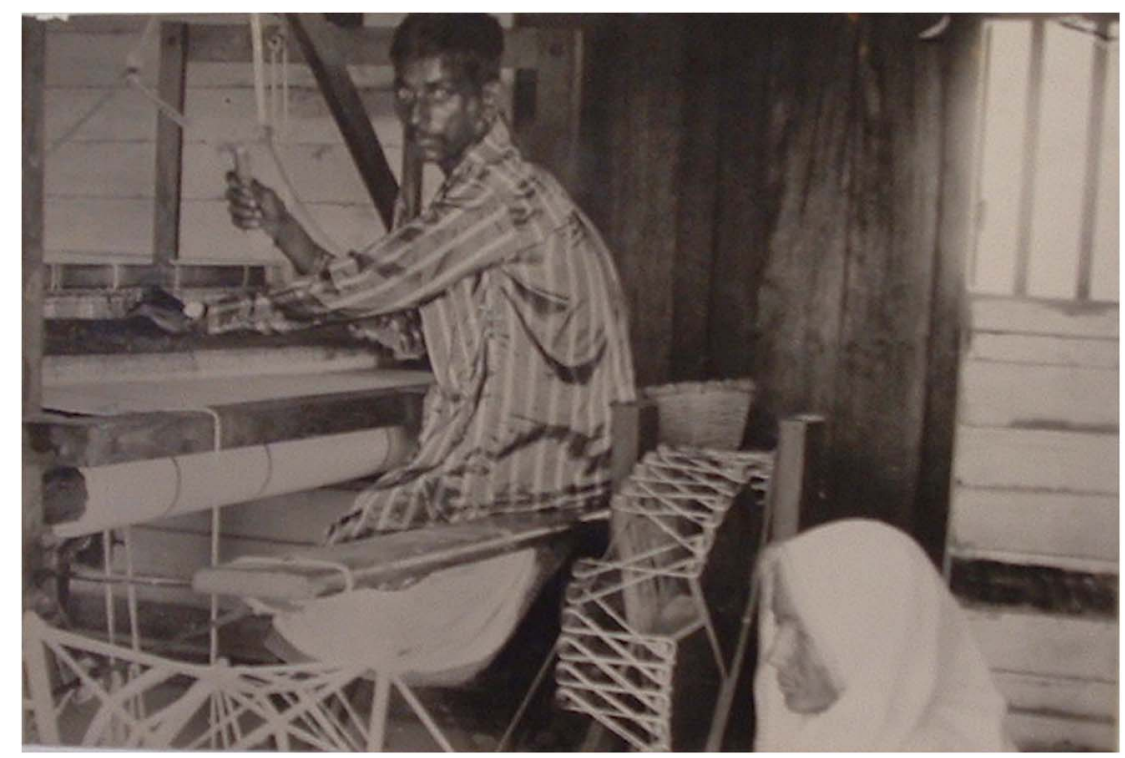

Figure 3. "Bantoo making convicts' clothing at Ferrar-Gunj”.

Ferrar Collection, Centre of South Asian Studies, University of Cambridge. Used by permission.

400 members of their families to the Andamans. Salvation Army General Frederick Coutts later likened Sheard to Richard Johnson, the first Anglican priest of Britain's penal colony in New South Wales. The Bhantus settled in three villages - Ferrargunj, Cadelganj, and Anikhet - where Sheard took charge of building houses and other structures, planting fruit trees, establishing other agricultural enterprises, the employment of his charges in the sawmill and Western India Match Company's match factory at Chatham (the only privately owned industry on the Islands), and setting up a handloom weaving factory (see Figure 3). Salvationists later said that during the first two or three years, the Bhantus neglected their cattle and refused to engage in settled cultivation. But the community soon became self-supporting. One man even developed a weaving business that employed twenty people. ${ }^{58}$ As Salvation Army Brigadier R.T. Hughes later put it:

Prison systems should not be merely vindictive, but should resemble schools of discipline providing education and correction; so that by the time a convict has

58. Salvation Army International Heritage Centre, London (SAIHC): IN/2/r: Papers from India, Northern Territory, I891-1993: “A Model Convict Settlement: Life in the Andaman Islands", n. d.; M.C.C. Bonington, Census of India, I93 I, Volume II: The Andaman and Nicobar Islands (Calcutta, I932), pp. 4I-43; Frederick L. Coutts, "I Had No Revolver": Edwin Sheard (London, 1943); Edwin H. Sheard, Sergeant-Major in the Andamans: Kanhaiya Gariba (St Albans, 1957), pp. I I-I 2; Edwin H. Sheard, "Reforming Robbers in the Andamans", The Officers' Review 
passed through the various classes or standards, he will be released and able to attain to full citizenship rights, and be able to carry on normally and naturally. ${ }^{59}$

Spurred on by the success of the scheme, in 1929, the British sent 170 Karwals, another so-called criminal tribe closely related to the Bhantus, to the Islands. However, the administration swiftly repatriated them, because they were found to be "totally unsuited" for settlement. ${ }^{60}$ During this period, finally, the government shipped North Indian Ranchis and Burmese Karen to the Andamans to work in the forest department. This was directly related to the Islands' specific labour needs. Indeed, when the administration wound down the Islands' sawmill in I93 I, the government sent most of them home. ${ }^{6 \mathrm{I}}$ Meanwhile, British administrators found the Bhantu of great interest, and for the I93 I census issued Captain Sheard with "a questionnaire on the cultural anthropology and ethnology of the Bhantus". With "unique" experience of daily contact with them, he assisted in the production of a detailed account of their "organization, habits and customs". This related almost entirely to their lives before resettlement in the Andamans, freezing them in time, though some reference was made to the loss of their particular dialect. ${ }^{62}$

Sheard and his wife left the Andamans after six years, and they were replaced by Major William Francis, who remained in the Islands for a decade, right up to the Japanese occupation in World War II (1942-1945). After ten years, with no special privileges on offer to converts, only sixtysix of the 295 Bhantu adults had become Christians. "It is better to win individually sincere souls who courageously step out to become seekers after truth", wrote Hughes, "than offer loaves and fishes and have an entire community as nominal Christians only". ${ }^{63}$ If the Army's hopes of mass conversion were not entirely realized, nevertheless the scheme was successful in supporting what Madhumita Mazumdar has described as Chief Commissioner Ferrar's “improving vision” for the larger development of the

(November 1937), pp. 535-540. General accounts of Salvation Army rehabilitation include Rachel J. Tolen, "Colonizing and Transforming the Criminal Tribesman: The Salvation Army in British India”, American Ethnologist, I 8:I (1991), pp. I06-I 25.

59. SAIHC: IN/2/r: Brigadier A.T. Hughes, officer commanding, Burma, "Life Among Lifers, Being a Short Account of the Ferrar Gunj Colony Run by the Salvation Army for the Government of the United Provinces, India, Among Life-Sentence (Murderer) Convicts and their Families in the Andaman Islands".

60. Report on the Administration of the Andaman and Nicobar Islands and the Penal Settlement of Port Blair, Ist December 1929 to 3 Ist March 1932 (Calcutta, 1932), p. 2. The report does not specify the reasons for their "unsuitability".

61. Bonington, Census of India, I93 I, Volume II, pp. 29-30; Report on the Administration of the Andaman and Nicobar Islands 1929-1932; F.A.M. Dass, The Andaman Islands (Bangalore, 1937), pp. 70-71.

62. Bonington, Census of India, I93 I, Appendix I: The Bhantus (language, pp. 39-4I).

63. Hughes, "Life Among Lifers", p. 24. The Salvation Army called insincere converts "rice Christians". 
Islands. This included large-scale dredging and other interventions into their landscape and environment. ${ }^{6}$ Indeed, whilst the Salvation Army had reservations about the effectiveness of the resettlement scheme, the British declared it an unambiguous success. They described Bhantus as "colonists", who had become "hardworking members of the community" ${ }^{65}$ Their number grew to 5 I 4 by the outbreak of World War II, after which all of those resettled under judicial sentence had served their time. ${ }^{66}$

\section{CONCLUSIONS}

Eurasians and Anglo-Indians occupy a central place in the history of the Andaman Islands. As convicts and licenced prisoners, they were vital social intermediaries between the British administration and Indian convicts, and following the recommendation of the abolition of transportation in I9I9-1920 government viewed them as potential settlers in the Andamans' transition from penal colony to free society. Race and class combined to produce specifically Anglo-Indian island formations that resembled those of the penal settlements in South East Asia, but differed from those of the mainland. Notably, free white Europeans employed in the subordinate classes of the Islands' administration became subsumed in the category "Anglo-Indian". In this sense, "Anglo-Indian" in the Islands denoted social origin more than it delineated hierarchies of race.

The number of free Anglo-Indian settlers in the Andamans was always limited, however, and after the failure of experimental pioneer migration in the I920s the British administration took advantage of the human outcomes of imperial repression on the mainland to further advance their colonization. Though the "volunteer" prisoner scheme largely failed to attract substantial numbers of migrants, the effects of British governance underlay more successful programmes, at least from a government perspective, for the coercive resettlement of Mapalahs and Bhantus, and their families, in the Andamans. Penal colonies such as the Andamans thus existed within the political borders of imperial colonies, and were subject to competing pressures regarding punishment and rehabilitation, and settlement and selfsufficiency. The Islands were, in this sense, a carceral periphery at the edge of empire that reveal a great deal about imperial governance in its Indian centre.

64. Anderson et al., New Histories of the Andaman Islands, pp. 29-6r.

65. Report on the Administration of the Andaman and Nicobar Islands and the Penal Settlement of Port Blair, Ist April 1938 to 3 Ist March 1939 (New Delhi, I940), p. 4.

66. A\&N Jails Department accession no. 203 Future of the Bhantu settlement: B.L. Pandey's note, I 5 June 1945; N.K. Paterson's note, is June 1945. See also Report on the Administration of the Andaman and Nicobar Islands and the Penal Settlement of Port Blair, Ist April 1937 to 3 Ist March 1938 (New Delhi, I939), pp. 2-3. 